African Crop Science Journal by African Crop Science Society is licensed under a Creative Commons Attribution 3.0 Uganda License. Based on a work at www.ajol.info/ and www.bioline.org.br/cs DOI: https://dx.doi.org/10.4314/acsj.v28i1.9S

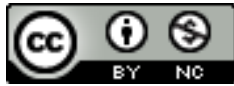

\title{
FACTORS INFLUENCING THE CHOICE OF MARKETING STRATEGIES AMONG CASSAVA MICROENTERPRISES IN KENYA
}

\author{
G.C. NGENOH, I.M. KARIUKI, E.W. GATHUNGU and S.K. KIPROP ${ }^{1}$ \\ Department of Agricultural Economics and Agribusiness Management,Egerton University, \\ P. O. Box 536-20115, Njoro, Kenya \\ ${ }^{1}$ Department of Economics, Egerton University, P. O. Box 536-20115, Njoro, Kenya \\ Corresponding author: ngenoffrey@gmail.com
}

\begin{abstract}
Cassava (Manihot esculenta L.) production and utilisation in Kenya face stiff competition from other major starchy food crops mainly maize, potatoes and wheat. This is due to the cyanide content in cassava which is lethal when roots are mishandled, leading to avoidance of the crop by potential consumers. This has affected the marketing of the crop and its products. The objective of this study was to analyse factors that influence the choice of marketing strategies among agripreneurs in cassava microenterprises in Kenya. A studywas conducted in Migori County (Kuria West, Suna East, Suna West and Uriri Sub-counties) in Kenya, using a semi-structured questionnaire, administered to a sample of 267 cassava micro enterprises. Results showed that the most used marketing strategies were pricing, product promotion, value addition and formation of a marketing alliance mostly in their combination. Multivariate Probit results showed that age, gender, education level, household size, major occupation (trading), marketing experience, seed money, entrepreneurial training, marketing information, market distance, group membership, farm gate and open-air marketing outlets significantly $(\mathrm{P}<0.05)$ influenced the choice of marketing strategies among cassava microenterprises. Therefore, cassava agripreneurs of microenterprises need to combine viable product lines and the marketing strategies that give maximum performance in order to increase their marketing shares and profits.
\end{abstract}

Key Words: Agripreneurs, Cyanide, Manihot esculenta, pricing

\section{RÉSUMÉ}

La production etl'utilisation du manioc (Manihot esculenta L.) au Kenya sontconfrontées à une concurrence féroce de la part d'autresprincipales cultures féculentes, principalement le maïs, les pommes de terre et le blé. Celaestdû à la teneurencyanure du manioc qui estmortellelorsque les racinessont mal traitées, ce qui conduit à l'évitement de la culture par les consommateurspotentiels. Cela a euune incidence sur la commercialisation de la culture et de sesproduits. L'objectif de cetteétudeétaitd'analyser les facteurs qui influencent le choix des stratégies de commercialisation des agripreneurs dans les microentreprises du manioc au Kenya. Uneétude a étémenéedans le comté de Migori (comtés de Kuria West, Suna East, Suna West et Uriri) au Kenya à l'aide d'un questionnaire semi-structuré, administré 
à un échantillon de 267 microentreprises de manioc.Les résultatsontmontré que les stratégies de marketing les plus utiliséesétaient le prix, la promotion de produits, la valeurajoutée et la formation d'une alliance de marketing principalementencombinaison. Les résultatsmultivariés de Probit ontmontré que l'âge, le sexe, le niveau de scolarité, la taille du ménage, la profession principale (négociation), l'expérience de marketing, l'argent de démarrage, la formation entrepreneuriale, l'information de marketing, la distance du marché, l' appartenance à un groupe, Les points de vente à la ferme et enplein air $(\mathrm{p}<0.05)$ ontfortementinfluencé le choix des stratégies de commercialisation parmi les microentreprises de manioc. Par conséquent, les agripreneurs de manioc des microentreprisesdoivent combiner des gammes de produitsviableset des stratégies de commercialisation qui donnentune performance maximaleafind'augmenterleurs parts de commercialisation et leursbénéfices.

Mots Clés : Agripreneurs, Cyanure, Manihot esculenta, tarification

\section{INTRODUCTION}

Cassava (Manihot esculenta L.) is a crop of strategic importance in Kenya, with the ability to withstand adverse climatic conditions (Lagat and Maina, 2017). This is, besides its abilities to improve the country's economy through relatively lower production costs compared to other starchy staple food crops such as maize, Irish potatoes and rice. Thus, cassava is regarded as a highly attractive and 'poverty aversion' crop in Kenya. As a strategic development, the Government of Kenya has embarked on promoting cassava as one of neglected and under utilised crops, in order to enhance the food base for the resource-poor people; and increase their incomes to mitigate poverty among rural communities (MOA, 2007; CIDP, 2018).

Strategic marketing among the microenterprises is inherent in their actual performance; as they must seek continuous growth with the aim of maintaining their sales and profit levels, for them to survive commercially. Commercialisation of products among the microenterprises helps them to fight poverty in their households (Collier and Dercon, 2014).

One of the challenges faced by agripreneurs while handling unprocessed agricultural commodities such as casssava tubers is failure to access appropriate marketing outlets quickly to earn relatively better prices. There is need to improve marketing strategies amongst cassava microenterprises for better performance in terms of higher sales turn over and profits. However, there is limited information about marketing strategies for the commonly traded cassava product lines in Kenya. Marketing is one of the key activities of any enterprising entity; thus, every enterprise requires good knowledge in marketing. The objective of this study was to analyse factors that influence the choice of marketing strategies by cassava microenterprises in Kenya.

\section{METHODOLOGY}

Study area. This study was conducted in Migori County, in south western part of Kenya. The County is located between Longitude $34^{\circ}$ East and $34^{\circ} 50^{\prime}$ East and latitude $0^{\circ} 24^{\prime}$ 'South and $0^{\circ} 40^{\prime}$ 'South. It is one of the leading counties in cassava production and marketing in the country and was purposely selected since little has been done on the marketing of the crop in this area.

The study was specifically done in four sub-counties, namely Kuria West (KW), Suna East (SE), Suna West (SW) and Uriri (U), where cassava production and marketing were the most concentrated in the County. The most common marketing outlets for food crops found in the area of study are the open-air market, marketing alliance, farm gate, roadside, shops, stall markets and mobile vendors. These marketing outlets are prevalent 
in Kenya with additional well-established supermarkets outlets and other food stores in urban areas.

Sample size and data collection. A survey was conducted in the year 2019, using a semistructured questionnaire administered to cassava microenterprises. A multi-stage sampling procedure was used to draw a sample size of 267 cassava agripreneurs from the County since there was no systematic list. The sample size was earlier computed using Cochran's (1977) formula.

$n_{0}=\frac{z^{2} p q}{\theta^{2}}$ Equation 1

Where:

$n_{0}$ is the sample size, $Z^{2}$ is the abscissa of the normal curve that cuts off an area $\alpha$ at the tails; $(1-\alpha)$ equals the desired confidence level at $94 \%) . e$ is the desired level of precision (acceptable marginal errors by the researcher: 0.05 for qualitative data and 0.01 for quantitative data) $p$ is the estimated proportion of an attribute that is present in the population, and $q$ is otherwise and is given as 1-p.

Table 1 shows proportionate study units calculated based on sub-counties geographical sizes since cassava microenterprises population was not known across the County.

TABLE 1. Proportionate study units distribution summary

\begin{tabular}{llcc}
\hline$N^{\circ}$ & Sub-county & $\begin{array}{c}\text { Area } \\
\left(\mathrm{Km}^{2}\right)\end{array}$ & $\begin{array}{c}\text { Target } \\
\text { respondents }\end{array}$ \\
\hline 1. & Kuria West & 332.5 & 74 \\
2. & Suna East & 207.3 & 46 \\
3. & Suna West & 282.8 & 63 \\
4. & Uriri & 380.7 & 84 \\
& Total & $1,203.3$ & 267 \\
\hline
\end{tabular}

Computed from the Cochran (1977)
The multi-stage sampling procedure was a three-stage involving cluster, purposive and random sampling approach. In the first stage, the County was initially segmented basing on the total number of sub-counties (eight subcounties) which formed clusters. In the second stage, the four sub-counties named above were purposely clustered. The third and final stage involved the random sampling of cassava marketers (cassava products agripreneurs) from each sub-county.

A semi-structured questionnaire was developed and administered to obtain primary data from the respondents. It was pretested in a sub-county (Rongo), which was not intended for the main study. The pre-test tool was realigned through distillation of the questions to achieve effectiveness during the interview sessions. Each interview session lasted on average 25 minutes, with maximum care to provide an enabling environment and flexibility to the respondent.

Econometric model. Decision on the marketing strategy selection is a discrete choice from among alternative strategies available to cassava microenterprises. Because only the cassava microenterprise's choice on a particular marketing strategy was evaluated, the following latent structure Univariate Probit model for the choice of each marketing strategy can be specified (Greene, 2012).

$y_{i}^{*}=\mathrm{X} \beta+\mu_{\mathrm{i}} \ldots \ldots \ldots \ldots \ldots \ldots \ldots \ldots \ldots \ldots \ldots$ Equation 3

$y_{i}=\left\{1\right.$ if $y_{i}^{*}=X \beta+\mu_{\mathrm{i}}>0 ; 0$ if $\left.y_{i}^{*} \leq 0\right\}$

Where:

$y_{i}^{*}$ is the binary latent variable for marketing strategy choice observed (observed if $y_{i}^{*}>0$, 0 otherwise); and $\mathrm{X}$ is a vector of householdspecific, institutional and socioeconomic factors determining marketing strategy choice.

However, cassava microenterprises might select one or more marketing strategies simultaneously, depending on the expected 
benefits and risks associated with each marketing strategy. The potential for simultaneous correlation across different marketing strategies suggests that a model addressing correlated choices is appropriate. In the presence of correlation among unobserved factors across choices, the Simple Probit or Logit Model produces biased estimates of choice probabilities as well as incorrect standard error for $\mathrm{b}$; and inferences based on those for determining critical factors determining choices lead to inconsistent results (Greene, 2012).

Multivariate Probit modelling techniques were appropriate for correcting such biases generated from correlation across choices (Greene, 2012), because they allow for possible simultaneous correlation across available choices. Hence, this study used a multivariate probit econometric technique to simultaneously model the influence of the set of independent variables on each of the different marketing strategy choice decisions, while allowing the unobserved (error terms) to freely correlate with each other (Mokhtarian and Tang, 2011; Arinloye et al., 2015).

The choice of marketing strategies. Pricing, product promotion, product improvement (value addition) and marketing alliances generate dichotomous data, for example, either cassava agripreneur chooses a strategy or not. The data might also be correlated, for example, choosing a pricing strategy could be positively or negatively related with the chosen product promotion strategy; and so to other strategies. This prompted the use of Multivariate probit as it is popularly used in modelling correlating data (Cappellari and Jenkins, 2003). The model is used in estimating matrix equations by maximum simulated likelihood methods. The variance covariance matrix of cross-equation error terms has values of 1 on the leading diagonal. The off diagonal elements are correlations to be estimated (pjk-pkj), and $p j k=1$ for $\mathrm{j}=\mathrm{k}$, for all $\mathrm{j}, \mathrm{k}=1 \ldots, m$. In our study, marketing strategy decision was conceptualised as a system of multiple-choice equations as denoted by equations 4 to 7 .

price adjustmen $_{i}^{*}=\mathrm{X}_{i}^{\prime} \beta_{1}+\varepsilon_{1 \mathrm{i}} \ldots .$. Equation 4

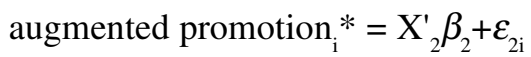
Equation 5

products improvemen ${ }_{t}^{*}=\mathrm{X}_{3}^{\prime} \beta_{3}+\varepsilon_{3 \mathrm{i}}$ Equation 6 strategic alliances $_{i}^{*} \mathrm{X}_{4}^{\prime} \beta_{4}+\varepsilon_{4 \mathrm{i}} \ldots \ldots .$. Equation 7 Where:

$\mathrm{E}(\varepsilon / x)=0, \operatorname{var}(\varepsilon / x)=1, \operatorname{var}(\varepsilon / x)=p$ and price adjustment ${ }_{i}$, augmented promotion, productimprovement $_{i}$, and strategic alliances ${ }_{i}$ are binary variables taking the value 1 when cassava microenterprise $i$ chooses them and 0 when otherwise. $X_{1}$ to $X_{4}$ are vectors of explanatory variables determining the respective strategy choice variables, $\beta$ 's are vectors of simulated maximum likelihood (SML) parameters estimated; $\varepsilon_{1}$ to $\varepsilon_{4}$ are correlated error terms in a seemingly unrelated multivariate probit model; and $p$ 's are tetrachloric correlations between endogenous variables.

\section{RESULTS AND DISCUSSION}

Descriptive statistics. The findings revealed mutual combinations of the marketing strategies used per microenterprise in the order of $91.76 \%$ agripreneurs use pricing strategy, $55.43 \%$ use product promotion, $47.94 \%$ use product-improvement strategy (value addition), and $8.61 \%$ were engaging other marketers (alliances). It is clear that pricing, product promotion and product improvement (value addition) strategies were highly used in the area of study; while the strategic marketing alliances were used the least. This may be attributed to the nature of the microenterprises not worth engaging other marketing partners. 
TABLE 2. Description and measurement of variables used in the Multivariate Probit model

\begin{tabular}{|c|c|c|c|}
\hline Variables & Description & Unit of measurement & Sign \\
\hline Age & Age of the cassava agripreneurs & Number of years & $+/-$ \\
\hline Gender & Gender of cassava agripreneurs & 0-Female, 1-Male & $+/-$ \\
\hline EducLvl & Education level for cassava agripreneurs & Years & + \\
\hline Hhsize & Household sizes for cassava agripreneurs & Persons & $+/-$ \\
\hline Majocc & Major occupation for cassava agripreneurs (trading) & 0-Trade, 1-Agriculture,2-Civil Servant & + \\
\hline Yrsell & Years of selling cassava products (marketing experience) & Years & + \\
\hline SeedMny & Access and use of seed money by cassava agripreneurs & 0-No, 1-Yes & + \\
\hline Enttraining & Entrepreneurial trainings received by cassava agripreneurs & 0-No, 1-Yes & + \\
\hline Mktinfo & Access to market information by cassava agripreneurs & 0-No, 1-Yes & $+/-$ \\
\hline Fgate & Farm gate outlet for cassava products & 0-No, 1-Yes & $+/-$ \\
\hline Rdside & Roadside as an outlet for cassava products & 0-No, 1 -Yes & $+/-$ \\
\hline Openair & Open air marketing outlet for cassava products & 0-No, 1 -Yes & $+/-$ \\
\hline Shop & Shopping center as marketing outlet for cassava products & 0-No, 1-Yes & $+/-$ \\
\hline Contrcted & Contracted cassava traders as marketing outlet for cassava products & 0-No, 1-Yes & $+/-$ \\
\hline Dst & Distance to the preferred market & Kilometres & $+/-$ \\
\hline Grpm & Group membership by cassava agripreneurs & 0-No, 1-Yes & $+/-$ \\
\hline GrpExtp & Group existence period & Years & $+/-$ \\
\hline
\end{tabular}


Therefore, based on the ratings (percentages), the use of pricing, product promotion and improvement strategies appear to be the ideal marketing strategies; while engaging marketing partners appears to be the least option of choice.

Empirical results. The choice of different marketing strategies among cassava microenterprises was influenced by factors such as demographic, institutional and marketing characteristics (Table 3). Multivariate Probit model results showed that age, major occupation (trading), years of selling cassava products (marketing experience), entrepreneurial trainings received, farm gate marketing outlet and group membership significantly influenced the choice of the pricing strategy among the cassava microenterprise. Also, gender of the respondents, household size, major occupation (trading), access and the use of seed money (credit/capital), access to marketing information, open-air market outlet, and joining a business-oriented group significantly influenced the choice of augmented promotion strategies. Product improvement or rather value addition as a marketing strategy was significantly influenced by the household size, access and the use of seed money, farm gate marketing outlet and distance to the preferred market. The choice of marketing alliance strategy was significantly influenced by age and education level for the respondents; and the access to marketing information. All marketing strategies were aimed at improving the performance of cassava microenterprises that resulted from relatively better profits earned.

These observations conformed to Staw (2013), who revealed that age is a factor that predicts success of a business as it implies extensive experience. Though the study reiterated that education leads to successful entrepreneurship, Hall (2013) did not acknowledge education as the key contributor to successful entrepreneurship; and thus pointed out that education plays a subsidiary role as real entrepreneurs are born and not made through education. The success of cassava microenterprises is positively related to age, extensive marketing experience, entrepreneurial group membership and training due to accumulated knowledge and acquired skills in the field of marketing as the major occupation. Seed money enables cassava microenterprises to access and sell their products into distant markets, thus maximising marketing opportunities for better performance.

The coefficients of the respondents' age was positively significant on formation of marketing alliance strategy, but negative for pricing strategy. As the respondents grew older, they were more unlikely to use the pricing strategy owing to reduced vibrancy required to search for better prices (negotiation) for their microenterprises. Furthermore, they resorted to depending on the other cassava marketers (marketing alliances). It is also likely that older traders were more satisfied with the little marketing margins (profits) and could not venture in outcompeting the young and actively more able traders, who always intended to maximise through price variation. This correspondingly translated into better marketing margins than for the aged traders. These observations conformed to the work of Egbetokun and Omonona (2012), who found out that age of farmers was inversely related to active market participation. This thus, implies that ageing tends to reduce the likelihood of engaging in commercialisation activities. Randela et al. (2008) observed that younger agripreneurs were relatively progressive, more receptive to new ideas of doing agribusiness and better understood benefits of commercialising agricultural commodities.

Hailua et al. (2015) acknowledged a positive relationship between age and commercialisation among the farmers in Tigray Region, Ethiopia. Although age advancement promotes commercial activities due to 
TABLE 3. Multivariate Probit model results for marketing strategies used by cassava microenterprises in Kenya

\begin{tabular}{|c|c|c|c|c|c|c|c|c|}
\hline \multirow[t]{2}{*}{ Variables } & \multicolumn{2}{|c|}{ Pricing } & \multicolumn{2}{|c|}{ Promotion } & \multicolumn{2}{|c|}{ Value addition } & \multicolumn{2}{|c|}{ Alliance } \\
\hline & $\beta$ & RSE & $\beta$ & RSE & $\beta$ & RSE & $\beta$ & RSE \\
\hline Age of CME head & $-0.0226 * *$ & 0.0090 & 0.0106 & 0.0103 & 0.0210 & 0.0144 & $0.0166^{*}$ & 0.0087 \\
\hline Gender of CME head & 0.1452 & 0.2156 & $0.4579 *$ & 0.2443 & 0.1112 & 0.3431 & -0.2692 & 0.2032 \\
\hline Education level for CME head (years) & -0.0336 & 0.0255 & 0.0107 & 0.0290 & 0.0021 & 0.0291 & $0.0482 *$ & 0.0248 \\
\hline Household sizes for CME heads & 0.0643 & 0.0403 & $-0.0789 * *$ & 0.0389 & $-0.0727 *$ & 0.0419 & -0.0444 & 0.0354 \\
\hline Major occupation for CME head (trading) & $0.3849 * *$ & 0.1950 & $0.6061 * * *$ & 0.2135 & 0.0328 & 0.2180 & 0.1274 & 0.1840 \\
\hline Years of selling cassava products & $\mathbf{0 . 0 3 5 8} *$ & 0.0199 & -0.0097 & 0.0164 & -0.0159 & 0.0215 & 0.0023 & 0.0146 \\
\hline Access and use of seed money & 0.0660 & 0.2499 & $0.5417 * *$ & 0.2637 & $0.7735 *$ & 0.4148 & -0.1175 & 0.2312 \\
\hline Entrepreneurial trainings received by CME heads & $0.4694 *$ & 0.2433 & -0.2601 & 0.2615 & -0.2051 & 0.3632 & -0.2182 & 0.2234 \\
\hline Access to market information & 0.2599 & 0.1969 & $0.3971 *$ & 0.2124 & 0.1772 & 0.2987 & $0.3343 *$ & 0.1892 \\
\hline Farm gate outlet & $-\mathbf{0 . 8 2 7 2} * * *$ & 0.2168 & 0.0806 & 0.2211 & $3.3528 * * *$ & 0.3226 & 0.1234 & 0.1940 \\
\hline Roadside as an outlet & 0.0637 & 0.2222 & -0.1725 & 0.2293 & 0.3638 & 0.2974 & 0.0780 & 0.2004 \\
\hline Open air marketing outlet & -0.0060 & 0.2710 & $6.6756 * * *$ & 0.3458 & -0.4282 & 0.4687 & 0.0795 & 0.2767 \\
\hline Shopping center as marketing outlet & 0.0283 & 0.1969 & 0.1328 & 0.2026 & -0.0143 & 0.2245 & 0.0689 & 0.1787 \\
\hline Contracted cassava traders as marketing outlet & -0.0422 & 0.2544 & -0.0962 & 0.3041 & -0.1821 & 0.3730 & 0.1397 & 0.2412 \\
\hline Distance to the preferred market $(\mathrm{Km})$ & 0.0114 & 0.0096 & -0.0116 & 0.0084 & $0.1093 * *$ & 0.0504 & 0.0033 & 0.0106 \\
\hline Group membership by CME head & $-0.4212 *$ & 0.2509 & $-0.5254 * *$ & 0.2473 & 0.0036 & 0.2750 & 0.1728 & 0.2179 \\
\hline Group existence in years & 0.0023 & 0.0283 & 0.0329 & 0.0283 & -0.0140 & 0.0270 & -0.0302 & 0.0226 \\
\hline Constant & 0.5470 & 0.6078 & -7.3574 & 0.8416 & -2.6101 & 0.5978 & -1.4813 & 0.6181 \\
\hline \multicolumn{9}{|l|}{ Multivariate probit regression } \\
\hline Number of observations & 267 & & & & & & & \\
\hline Wald Chi2 (68) & 2164.95 & & & & & & & \\
\hline Log pseudo likelihood & -473.1674 & & & & & & & \\
\hline Prob $>$ Chi2 & 0.0000 & & & & & & & \\
\hline
\end{tabular}

$*, * *, * * *$ Denotes significance levels at 10,5 , and 1\%, respectively; CME $=$ Cassava microenterprise, $\mathrm{Km}=$ kilometres 
accumulation of knowledge and skills from the farming experience, increase in age among cassava agripreneurs draws uncertainties about market prices because of limited access to market information, therefore, depending on others in marketing.

The coefficient for the gender of cassava traders was positively significant on using promotion strategy during selling cassava products (Table 3). Being female traders increased the probability of promoting the products in the markets, owing to their superiority unlike their male counterparts. This was probably because males were less associated with food commodities in the markets; specifically selling cassava products. Agwu et al. (2015) argued that a man's social life is less interactive than for a woman; thus lowering males' participation in cassava marketing activities. Furthermore, males engage mostly in selling high-value commodities for fast and better earnings.

The study findings affirmed that male agripreneurs prefer quick 'money-earning' transactions, compared to their female counterparts who are highly motivated by selling food commodities regardless of their monetary values (Agwu et al., 2015). This contradicts the study by Forsythe et al. (2016), who revealed that in Nigeria, both men and women actively participated in cassava commercial activities equally; therefore, they should be emulated for better performance of cassava microenterprises. This implies that socio-culture has a marked influence of cassava agripreneur behaviour in the choice and participation in agricultural produce marketing.

The number of years spent in school by the cassava agripreneurs was positively related to the formation of strategic marketing alliances (Table 3 ). This implies that more years of learning translated into more ideas, skills and knowledge on how to achieve marketing objectives through partnerships in cassava trade. This inference conforms to the findings of Randela et al. (2008) and Enete and
Igbokwe (2009), who argued that education equips agripreneurs with better production and managerial skills, which result in their increased chances of market participation; such skills are crucial when making decisions.

The coefficient of household sizes on cassava agripreneurs was significant, but negative on augmented promotions and value addition strategies (Table 3). This suggests that the larger the household size, the less likelihood to practice cassava value addition and promotion of cassava-based products. Large households tended to diminish the potential availability of cassava products for value addition and for sale in general (Olwande and Mathenge, 2012). This observation suggests that cassava product advertisement (as promotion) through the media as part of product promotion is unlikely, owing to the additional costs it entails, against the meagre incomes of cassava agripreneurs. Large households, however, tend to reduce the commodities through home consumptions, hence discouraging value addition as the available quantities fairly insufficient. Siziba $e t$ al. (2011) believes that larger households consume large proportions of outputs, leaving little for sale; hence reducing the likelihood of participating in marketing. This argument contradicts that of Jaleta et al. (2010), who stated that large household sizes encourage market participation perhaps through increased production due to availability of family labour.

This study has demonstrated that marketing activity/trading forms a major occupation for the cassava agripreneurs and takes a large portion of their working time daily (Table 3). Results showed a positive coefficient of major occupation with regard to the usage of pricing and augmented promotion strategies; while marketing their commodities. Being a cassava trader related positively to the use of pricing and promotion strategies. This implies that the two strategies were highly and statistically significant towards achievement of the occupation objectives. It translates into improved performance of cassava 
microenterprises since positive marketing margins (profits) and sales turnover in the long run. This resulted from the trading as a norm which offers tangible experience; which is a proxy to success of a business (micro enterprise) Saleem (2012).

Years of selling cassava-based products built up the marketing experience among the cassava microenterprises heads (Table 3). The coefficient of years of selling cassava was positively significant on using pricing strategy. This implies that cassava agripreneurs were more likely to apply the pricing strategy with additional years in marketing. This further indicates that as marketing period increases, traders gain technical knowledge on how to increase their marketing margins (revenues). Employment of various marketing strategies yields to enhanced marketing experience because long time traders tend to be more efficient and possess greater knowledge and skills in marketing (Boeker and Wiltbank, 2005). Pricing strategy involves negotiation skills built through marked experience as explained by their statistically significant relationship. Therefore,cassava agripreneurs' marketing capacities could not only be built through education, but also through experience.

The coefficient of seed money in support of cassava microenterprises in the regression model, positively influenced product promotion and value addition among cassava microenterprises in Kenya (Table 3). Seed money in this study refers to any form of cash that was used by the cassava microenterprises heads to improve the performance of their enterprises. Other studies referred to it as credit (Martey et al. 2012; Adejobi and Akinola, 2013). Access to and use of seed money among cassava micro enterprises was found to boost their abilities to using product promotion strategy. Cassava micro enterprises were more likely to promote their products, through provision of good packaging materials to customers, travelling to various events where they could sell the commodities (mobile vendors), thus increased sales turnovers. Moreover, there was also increased likelihoods of obtaining resources like technical services (trainings) and assets (equipment) used in value addition.

The coefficient of entrepreneurial training received by the cassava agripreneurs was positively significant only to pricing strategy (Table 3). Pricing strategy was highly attributed to getting marketing information either from other market participants or service providers. Getting training from service providers acted as networks for disseminating information and this would be likely to improve commercialisation (Rahut et al, 2015). Contrary to the expectation, trainings offered to cassava agripreneurs had no significant effect on their ability to improve and promote cassava products, as well as forming alliance in marketing. Normally, such trainings contribute to development of new products due to generation of new ideas in return (Elnaga and Imran, 2013; Karaam, 2019). A possible explanation for the unexpected behaviour could be that since the commodity in the area of study was not industrially processed, traders were used to the ordinary ways of improving the product (traditional value addition), whose scope of benefits and marketability are dismal.

Access to market information by entrepreneurs in cassava microenterprises was positively significant on using product promotion and marketing alliance strategies (Table 3). Having efficient and reliable marketing information sources resulted into knowing precisely what the consumers needed, while increasing the capabilities of partnership. Technically, this suggests that getting the information could reduce prices uncertainties, while increasing the bargaining powers among cassava microenterprises heads. Sigei et al. (2015) affirmed that farmers getting prices information at their farms were less likely to go and sell at urban markets, as they would try to escape the transaction costs, which reduces their potential profits. This is 
because they are in a position to calculate the opportunity costs.

Although the coefficient of farm gate marketing outlet was negatively significant on pricing strategy, it was positively significant onvalue addition strategy (Table 3 ). The negative relationship between the farm gatemarketing outlet and pricing strategy was because farm gate prices of all agricultural commodities were relatively lower than in the standard markets (Abu et al., 2016).This implies that cassava microenterprises were not likely to vary prices, thus they were price takers while at their homes.

Farm gate marketing outlets had a positively significant influence on cassava value-addition strategy (Table 3). This confirmed that adding value cassava tubers increases the likelihood of selling them at a fair price. This study found cassava agripreneurs did value addition at different nodes through washing, sorting, peeling and chopping, sun drying to fermentation. Furthermore, at least one of the value addition activities was done to increase the likelihood of selling the product. Since raw tubers were bulky, heavy and of less monetary value, it was ideal to add value so as to increase the shelf life hence selling easily at distant markets and also fetching better prices.

The coefficient of selling cassava products in an open-air market had a positive effect and statistically was significant on promotional marketing strategy (Table 3). This implied that the open-air marketing outlet was more effective and ideal for selling the products, since various forms of product promotion were easily done. Product display as a way of informing market clients about the availability of cassava products was a form of product promotion strategy. In an open-air market, there were many sellers of the same commodities (in terms of unit of selling and quality) and to convince the buyers to buy from them, they needed to promote the products strategically. Provision of carrier bags (packaging materials) to buyers increased their likelihoods of selling the products relative to who were giving none.

The coefficient for distance to the preferred market was positively significant on cassava value-addition strategy (Table 3). This implied that since fresh cassava tubers are bulky, heavy and of less monetary value; chopping, fermenting and drying as forms of value addition were worth doing to increase chances of selling at distant and preferred markets. Through value addition, price uncertainties and transaction costs in terms of transport costs would be reduced; hence encouraging participation in distant preferred markets. This was in contrast with Martey et al. (2012) and Ochieng et al. (2015), who argued that an increase in distance to the market reduced market participation because of increased marketing costs (transaction costs), which was the deterrent to market participation. Several other researchers also found out that increase in distance to the market limited market access among smallholder farmers (Omiti et al., 2009; Gebremedhin and Jaleta, 2010; Agwu, 2012).

The coefficient of joining agripreneurial groups was significant, but negative on using pricing and product promotion strategies (Table 3). The outcome was rather surprising; it showed that cassava microenterprises heads who were in different agripreneurial groups were unlikely to have exchanged ideas on pricing and product promotional strategies. Group membership has benefits to participants and the study expected positive relationships. This is because agripreneurs members were likely to share marketing ideas and information as well as increased bargaining power relative to when operating in isolation (Shiferaw et al., 2006). Sewando et al. (2011) reported that poor organisation and coordination of farmers (agripreneurs) makes it difficult for them to access lucrative markets. The results, therefore, predicted well the reason why cassava micro enterprises were not performing well in the area of studies and it should be 
reversed to realise better performance of their micro enterprises in their core activities.

\section{CONCLUSION}

The analysis carried out revealed that main factors that positively contribute to choice of marketing strategies among the cassava agripreneurs in Kenya are their age, gender, education level, household sizes, major occupation, years of selling the products (marketing experience), access and use of the seed money, entrepreneurial trainings, access to market information, farm gate and open air marketing outlets. Furthermore, distance to the preferred markets and membership to agripreneurs' groups contributed to the choice of the strategies. Major occupation (trading), increase in marketing experience and entrepreneurial trainings increased the likelihood to pricing strategy while increment in agripreneurs' age, use of farm gate outlet and group membership lowering its likelihood of usage.

Being a female agripreneur, access to seed money (capital) and market information, many years marketing the products and selling inopen-air markets increase the likelihood of promoting cassava products. Seed money, farm gate outlet and increase in distance to the preferred markets increase the likelihood of cassava value addition to increase and maintain quality and for better profits. However, large households reduce the amount of cassava quantities making it unworthy to add value. Aged and educated agripreneurs with the seed money and marketing information had high probability to form marketing alliances (partnerships) to ease marketing of the commodities.

\section{ACKNOWLEDGEMENT}

The authors are grateful to the MasterCard Foundation and Regional Universities Forum for Capacity Building in Agriculture
(RUFORUM) for funding research and publication cost through the Transforming African Agricultural Universities to meaningfully contribute to Africa's growth and development (TAGDev) Program.

\section{REFERENCES}

Abu, B., Issahaku, H. and Nkegbe, P. 2016. Farmgate versus market centre sales: A multi-crop approach. Journal of Agricultural and Food Economics 4(21):1-16. doi: 10.1186/s40100-0160065-6.

Agwu, N. 2012. Determinants of profitability among plantain marketers in Abia State, Nigeria. Journal of Development Studies 7(1):49-58.

Agwu, N.M., Anyanwu, C.I., and Kalu, U.H. 2015. Factors influencing cassava value addition by rural agribusiness entrepreneurs in Abia State, Nigeria. Journal of Management, Economic Engineering in Agriculture and Rural Development 15(3):5.

Arinloye, D-D.A.A, Stefano, P., Anita, R.L., Ousmane, N.C., Geoffrey, H. and Onno, S.W.F.O. 2015. Marketing channel selection by smallholder farmers. Journal of Food Products Marketing 21(4):337357.

Boeker, W. and Wiltbank, R. 2005. New venture evolution and managerial capabilities. Organization Science (16):123133.

Cappellari, L. and Jenkins, S.P. 2003. Multivariate probit regression using simulated maximum likelihood. The Stata Journal 3(3):278-94.

CIDP. 2018. County integrated development plan. Retrieved from http://pshpkenya.org/ wp-content/uploads/2016/04/MigoriCounty-Integrated-Development-Plan.pdf on $3^{\text {rd }}$ May 2019.

Cochran, W.G. 1977. Sampling Techniques ( $3^{\text {rd }}$ Edition). New York: John Wiley \& Sons. 
Collier, P. and Dercon, S. 2014. African Agriculture in 50 years: Smallholders in a rapidly changing World? World Development, Elsevier 63(3):92-101.

Egbetokun, O.A. and Omonona, B.T. 2012. Determinants of farmers' participation in food market in Ogun State. Global Journal of Science Frontier Research Agriculture and Veterinary Sciences (12):9.

Elnaga, A. and Imran, A. 2013. The effect of training on employee performance. European Journal of Business Management 1(5):137-147.

Enete, A.A. and Igbokwe, E.M. 2009. Cassava market participation decisions of producing households in Africa. Tropicultura 27(3):129-136.

Forsythe, L., Posthumus, H. and Martin, A. 2016. A crop of one's own? Women's experiences of cassava commercialization in Nigeria and Malawi. Journal of Gender, Agriculture and Food Security 1(2):110128.

Gebremedhin, B. and Jaleta, M. 2010. Commercialization of smallholders: Is market participation enough? Paper presented at the Agricultural Economists Association of South Africa (AEASA) Conference, Cape Town, South Africa.

Greene, W.H. 2012. Econometric Analysis. ( $7^{\text {th }}$ edition). New Jersey: Pearson Hall.

Hailua, G., Manjureb, K. and Aymutc, K.M. 2015. Crop Commercialisation and smallholder farmers' livelihood in the Tigray Region, Ethiopia. Journal of Development and Agricultural Economics 7(9):314-322.

Hall, B.H. 2013. The relationship between firm size and firm growth in the US manufacturing sector. The Empirical Renaissance in Industrial Economics 35(4): 583-606.

Jaakkola, M., Moller, K., Parvinen, P., Evanschitzky, H. and Muhlbacher, H. 2006. Strategic marketing and its effects on business performance: Moderating effect of country-specific factors. Master's Thesis in Industrial Engineering and
Management.Helsinki University of Technology, Finland. 137pp.

Jaleta, M., Gebremedhin, B. and Hoekstra, D., 2010. Smallholder commercialization: Processes, determinants and impact. Improving productivity and market success of Ethiopian farmers improving market opportunities. International Livestock Research Institute. Discussion Paper (18):1-55.

Jones, S. 2007. Exploring corporate strategy: Text and Cases. $8^{\text {th }}$ Edition.

Karaam, A.A. 2019. The impact of training and development on different cultural employees performance through interaction employees motivation in Erbil public and private Banks. Mediterranean Journal of Social Sciences 10(1):193-206. doi: 10.2478/mjss-2019-0017.

Kotler, P. 2007. Marketing: An introduction. New Jersey: Pearson Education Inc.

Kotler, P. and Armstrong, G. 2006. Principles of Marketing. Upper Saddle River, New Jersey, Pearson Prentice Hall, $11^{\text {th }}$ Edition. $651 \mathrm{pp}$.

Lagat, J. K. and Maina, M. C. 2017. A gender and decent work analysis of cassava production and on-farm processing, in Kuria West Sub-county, Kenya. African Journal of Agricultural Research 12(31):2533-2544.

Martey, M., Ramatu, M. A-H. and Kuwornu, J. K. M. 2012. Commercialization of smallholder agriculture in Ghana: A Tobit regression analysis. African Journal of Agricultural Research 7(14):2131-2141.

MOA. 2007. National policy on cassava industry: Policy reforms to improve production, research, marketing and regulation in the cassava industry. Report by the Ministry of Agriculture Republic of Kenya,

Mokhtarian, P. and Tang, W. 2011. Trivariate Probit Models of pre-purchase/purchase shopping channel choice: Clothing purchases in Northern California. 
Institution of Transportation Studies. Research Report. UCD-ITS-RR-11-15.

Ochieng, J., Knerr, B., Owuor, G. and Ouma, E. 2015. Agricultural commercialization and household food security: The case of smallholders in Great Lakes Region of Central Africa. Paper presented at the International Conference of Agricultural Economists, Milan, Italy.

Olwande, J. and Mathenge, M. 2012. Market Participation among poor rural households in Kenya. The International Association of Agricultural Economists (IAAE) Triennial Conference, Foz do Iguacu, 18-24 August 2012.

Omiti, M., Nyanamba, D. and Mccullough, E. 2009. Factors influencing the intensity of market participation by smallholder farmers: A case study of rural and peri-urban areas of Kenya. African Journal of Agricultural Resources and Economic 3(1):57-82.

Rahut, D., Ali, A., Castellanos, V. and Sahoo, P. 2015. Market participation by subsistence farmers: Evidence from the Himalayas. Journal of Animal and Plant Sciences 25(6):1713-1721.

Randela, R., Alemu, Z.G. and Groenewald, J.A. 2008. Factors enhancing market participation by smallscale cotton farmers. Agrekon 47(4):451-469. http:// dx.doi.org/10.1080/03031853.2008. 9523810

Saleem, M.A. 2012. The impact of socioeconomic factors on small business success. Malaysian Journal of Society and Space 8(1):24-29.

Sewando, P.T., Mdoe, N.Y.S. and Mutabazi, K.D.S. 2011. Farmers' preferential choice decisions to alternative cassava value chain strands in Morogoro rural district, Tanzania. Agricultural Journal 6(6):313321. http://dx.doi.org/10.3923/aj.2011. 313.321.

Shiferaw, B., Obare, G. and Muricho, G. 2006. Rural institutions and producer organizations in imperfect markets: Experiences from producer marketing groups in semi-arid Eastern Kenya. CAPRI Working Paper 60 jointly released as ICRISAT Socioeconomics and Policy Working Paper Series No. 23. Patancheru, Andhra Pradesh, India.

Sigei, K.G., Bett, K.H., Kiprop, K.J. and Odipo, O.O. 2015. Factors influencing the choice of marketing outlets among smallscale pineapple farmers in Kericho County, Kenya. International Journal of Regional Development 2(2). doi: 10.5296/ijrd. v2i2.6237

Siziba, S., Nyikahadzoi, K., Diagne, A., Fatunbi, A. and Adekunle, A. 2011. Determinants of cereal market participation by sub-Saharan Africa smallholder farmer. Journal of Agricultural and Environmental Studies 2(1):180-193.

Staw, B.M. 2013. Psychological dimensions of Organisational Behaviour. ( $3^{\text {rd }}$ Edition). Sydney. MacMillan. 516 pp. 